Available online at GSC Online Press Directory

GSC Biological and Pharmaceutical Sciences

e-ISSN: 2581-3250, CODEN (USA): GBPSC2

Journal homepage: https://www.gsconlinepress.com/journals/gscbps

(RESEARCH ARTICLE)

\title{
Extraction, production and characterization of biodiesel from shea butter (Vitellaria paradoxa C. F. Gaertn) obtained from Hadejia, Jigawa State, Nigeria
}

\author{
Datti Yau 1,*, Musa Ibrahim 1, Isma'il Salihu 1, Mustapha Abdulhadi 1, Muhammad Muhammad Sani ${ }^{1}$, Ado
} Abubakar Sulaiman ${ }^{1}$ and Ahmad Ummi Umar ${ }^{2}$

${ }^{1}$ Department of Chemistry, Yusuf Maitama Sule University, Kano.

${ }^{2}$ Department of Science Laboratory Technology, School of Technology Kano.

Publication history: Received on 08 June 2020; revised on 26 June 2020; accepted on 27 June 2020

Article DOI: https://doi.org/10.30574/gscbps.2020.11.3.0168

\begin{abstract}
Biodiesel, a form of diesel fuel, is an alternative fuel similar to the conventional diesel (the fossil) and can be produced from vegetable oils, animal oils and fats, tallow and waste cooking oils. In this study, oil was extracted from shea butter, and then subjected to transesterification process to convert it to biodiesel. Both the oil and the biodiesel were characterized using the standard procedures. The results showed that the oil has a density of $923.82 \mathrm{Kgm}^{3}$, refractive index of 1.464 , viscosity of $4.5 \mathrm{~mm}^{2} / \mathrm{s}$ at $40^{\circ} \mathrm{C}$, acid value of $1.84 \mathrm{mgKOH} / \mathrm{g}$, saponification value of $189.53 \mathrm{mgKOH} / \mathrm{g}$, flash point of $338^{\circ} \mathrm{C}$ and iodine value of $35.52 \mathrm{mgI}^{2} / \mathrm{g}$. While the results for the biodiesel showed that it has a density of $887.61 \mathrm{Kgm}^{3}$, refractive index of 1.441 , viscosity of $3.62 \mathrm{~mm}^{2} / \mathrm{s}$ at $40^{\circ} \mathrm{C}$, acid value of $0.37 \mathrm{mgKOH} / \mathrm{g}$, saponification value of $265.81 \mathrm{mgKOH} / \mathrm{g}$, flash point of $96^{\circ} \mathrm{C}$ and iodine value of $34.24 \mathrm{mgI}^{2} / \mathrm{g}$. These results were found to be within the ranges of American Society for Testing and Materials (ASTM) specification.
\end{abstract}

Keywords: Biodiesel; Shea butter; Shea butter oil; Transesterification

\section{Introduction}

The World relies on fuels (in the form of petroleum) from fossils as the major source of all energies needed, utilized and consumed. However, these fossils are seemingly gradually diminishing, and may be finished in the near future. More so, the constant and continuous usage of petroleum and petroleum products is a factor that is capable of polluting the air, and increasing the rate of global warming, as well as other problems caused by high concentration of carbon dioxide in the air (Shay, 1993). Thus, the menace of the ever growing demand for energy all over the world, and the negative effect of carbon dioxide emissions associated with the use of fuels from fossils has necessitated the need to search for other alternative energy sources which may be renewed and with lower environmental impact than the fossil fuels (Atabani et al., 2013; Ho et al., 2014). By this, scientists and researchers were forced to consider the possibility of exploring other alternative sources of energy with renewability, and which may be more environmentally friendly (Kotoko et al., 2017; Tulashie and Salifu 2017).

Among the possible remedy to this problem is the use of biodiesel. Biodiesel has been identified as the most significantly environmentally friendly and less problematic source of energy (Mulugetta, 2009). Biodiesel can be obtained from easily biodegradable renewable and nontoxic biological sources which have low gaseous emissions, and this makes them environmentally beneficial (Mulugetta, 2009; Enweremadu and Alamu 2011). Biodiesel can be the best alternative fuel for diesel engines because of its technical, environmental and economic benefits, as well as its ability to prolong the life of an engine by $20 \%$ and its ability to reduce the rapid occurrence of heat-related damaged (Enweremadu et al., 2011).

\footnotetext{
* Corresponding author: Datti Yau
} 
The use of some edible vegetable oils, like soybean oil, sunflower oil, palm oil and rapeseed oil, as well as some animal fats as sources of biodiesel was used to overcome the problems and menace associated with the use of fossils fuel (Ramadhs et al., 2004; Sarin et al., 2007). However, the use of such edible vegetable oils and animal fats for the production of biodiesel has recently been of great concern because they tend to compete with food materials. Now with the ever increasing demand for vegetable oils as food, and their ever increasing costs, it is becoming more difficult to use these oils for the production of fuel, thus the contribution on non-edible oils for the production of biodiesel will be significant (Arjun et al., 2008).

Some notable examples of non-edible oilseed crops include jatropha tree (Jatropha curcas), rubber seed tree (Hevea brasilliensis), tobacco seed (Nicotiana tobacum), mahua (Madhuca indica), castor bean seed (Ricinus communis), neem (Azadirachta indica), karanja (Pongamia pinnata), etc (Ayhan et al., 2016). The production of biodiesel from different non-edible oil seed crops has been extensively investigated over the last few years by many researchers (Ghadge and Raheman 2005; Phadi and Singh 2010; Gimbun et al., 2013; Heroor and Bharadwaj 2013; Thangaraj et al., 2014; Maitera et al., 2017; Samuel et al., 2018). One of the most highly promising sources of biodiesel is the shea butter from shea nut tree (Vitellaria paradoxa C.F. Gaertn, formerly known as Butyrospermum parkii). It grows naturally and commonly in Africa, and it is less expensive in its raw state.

The aim of this study is to extract, produce and characterize biodiesel from shea butter, and then compare the physicochemical and fuel properties of the shea butter oil before and after biodiesel production.

\section{Material and Methods}

\subsection{Sample Collection}

The shea butter kernels were obtained from Hadejia in Jigawa state, Nigeria. The kernels were identified by a plant taxonomist from the Department of Biological Sciences, Yusuf Maitama Sule University, Kano, with a voucher number YUHAN 0046 assigned, and a sample specimen deposited at the herbarium.

\subsection{Sample Preparation}

The kernels were crushed into pieces, air-dried under shade, and then grounded to fine powder then stored in a dry container (Bayero et al., 2019).

\subsection{Solvent Extraction}

Hundred grams (100 g) of the powdered sample was soaked in $500 \mathrm{ml}$ of absolute ethanol for three days (72 hrs) and then stored away from direct light. The supernatant was later decanted and filtered using filter paper. The filtrate was then evaporated to dryness and stored in a sample bottle at room temperature to avoid any further biological degradation (Bayero et al., 2019).

\subsection{Transesterification of the 0il}

The powdered kernel sample $\left(20 \mathrm{ml}\right.$ ) was mixed with $100 \mathrm{~cm}^{3}$ of potassium methoxide (obtained by dissolving $0.5 \mathrm{~g}$ of $\mathrm{KOH}$ in $100 \mathrm{~cm}^{3}$ of methanol). The mixture was stirred at $600 \mathrm{rpm}$ and at a reaction temperature of $50^{\circ} \mathrm{C}$ for $2 \mathrm{hours}$ in a volumetric flask. The mixture was then poured into a separating funnel and then allowed to stay overnight to ensure the completion of the reaction, and for the mixture to completely separate into two layers of biodiesel and the more dense glycerol settling at the bottom. The denser glycerol was then drained off, while the biodiesel was washed with distilled water, with the possible impurities that can affect combustion and exhaust emission all removed (Canakci and Van Gerpen 1999). The biodiesel was then allowed to settle for 1 hour to separate into two layers of the pure biodiesel and hydrated methanol, and these were separated using separating funnel.

\subsection{Determination of Density}

This was done using density bottles. The density bottles were washed, dried and then labeled. Some amount each of the test samples (pure oil and the transesterified oil) were transferred into the density bottles and then the weights determined and recorded (Ike et al., 2018).

The respective densities were then calculated from the obtained results: 
Datti et al. / GSC Biological and Pharmaceutical Sciences, 2020, 11(03), 208-215

$$
\begin{aligned}
\text { Density } & =\frac{\text { Weight of Oil }}{\text { Volume of OIl }} \\
\text { Specific Gravity } & =\frac{\text { Weight of the Oil }}{\text { Weight of the Water }} \\
& =\frac{C-A}{B-A}
\end{aligned}
$$

Where,

$\mathrm{A}=$ Weight of Empty Density Bottle $=\mathrm{A}$

$\mathrm{B}=$ Weight of Bottle + Water $=\mathrm{B}$

$\mathrm{C}=$ Weight of Bottle + Oil $=\mathrm{C}$

$\mathrm{B}-\mathrm{A}=$ Weight of Water $=\mathrm{B}-\mathrm{A}$

C- A = Weight of Oil.

\subsection{Determination of Refractive Index}

The refractive index of the oil and the biodiesel samples were determined according to the AOAC method (2000) using an Abbe refractometer (NYRL 3-Leica Mark, Leica Inc., Buffalo, New York).

\subsection{Determination of Viscosity}

The viscosities of the two samples were determined using an Ubbelohde glass capillary viscometer according to the procedure reported by Ike et al., (2018)

\subsection{Determination of Acid Value}

The acid values of the two test samples were determined by transferring $2 \mathrm{~g}$ each of the samples into a conical flask, and $50 \mathrm{~cm}^{3}$ of petroleum ether added and then gently mixed. Then $50 \mathrm{~cm}^{3}$ of ethanol was added into the mixture and titrated with $0.1 \mathrm{M} \mathrm{KOH}$ to pink colour (AOAC, 1990). The acid value was calculated using the formula:

$$
\begin{gathered}
\text { Acid Value }(\mathrm{mg} \mathrm{KOH} / \mathrm{g})=\frac{\text { Titre Value } x \text { Normality } x 56.1}{\text { Weight of Sample }} \\
\begin{array}{c}
\text { \% Free Fatty Acid }=\frac{\text { Titre Value } x 28.2 \times \text { Normality }}{\text { Weight of Sample }} \\
1 \mathrm{~cm}^{3} \text { of } 1 \mathrm{M} \mathrm{KOH}=56.1 \mathrm{mg} \text { of } \mathrm{KOH}
\end{array}
\end{gathered}
$$

\subsection{Determination of Saponification Value}

The saponification values of the test samples were determined by weighing $2 \mathrm{~g}$ each of the test samples into a round bottomed-flask and $25 \mathrm{~cm}^{3}$ of alcoholic $\mathrm{KOH}$ added. The flask was then fitted onto a condenser and the solution was refluxed for 10 minutes, and $1 \mathrm{~cm}^{3}$ of phenolphthalein was added to the refluxed mixture and then titrated against 0.2 $\mathrm{M} \mathrm{HCl}$, with the titre value recorded (Alajtal et al., 2018). The procedure was repeated with $25 \mathrm{~cm}^{3} \mathrm{KOH}$ as blank and the test titre value was recorded. The difference between the blank and the tested titre gives the amount of KOH absorbed by the oil. The saponification value was calculated using the formula:

$$
\text { Saponification Value }=\frac{(S-B) \times M \times 56.1}{\text { Weight of Sample Used }(g)}
$$

Where,

$\mathrm{B}=$ Blank Titre Value

$\mathrm{S}=$ Sample Titre Value

$\mathrm{M}=$ Molarity of $\mathrm{HCl}$

56.1 = Molar Mass of $\mathrm{KOH}$ 


\subsection{Determination of Flash Point}

The flash points of the two samples were determined using automatic Pensky Marten flash point tester, where the samples were poured into the cup of the tester and then covered. A flame of specified size was directed to the cup at an internal until the vapour above the samples ignited, and then the thermometer readings were recorded and the flash points corrected (Kanna et al., 2017).

\subsection{Determination of Iodine Value}

Each of the two samples ( $0.26 \mathrm{~g}$ each) was transferred into glass stoppered-flask containing $10 \mathrm{~mL}$ of cyclohexane. Then $20 \mathrm{~mL}$ of Wijs solution (iodine monochloride dissolved in acetic acid) was added to the flask, and the flask was then stoppered and allowed to stand for 30 minutes in the dark at a temperature of $25^{\circ} \mathrm{C}$ after which $20 \mathrm{~mL}$ of $10 \% \mathrm{KI}$ solution was added. The mixture was titrated against $0.1 \mathrm{M} \mathrm{Na}_{2} \mathrm{~S}_{2} \mathrm{O}_{3}$ using starch as the indicator. A blank was carried out and the iodine value was calculated using the following formula (AOAC, 1990).

$$
\text { Iodine Value }=\frac{12.69 \times C\left(V_{1}-V_{2}\right)}{\text { Weight of Sample }(g)}
$$

Where,

$\mathrm{C}=$ Concentration of $\mathrm{Na}_{2} \mathrm{~S}_{2} \mathrm{O}_{3}$

$\mathrm{V}_{1}=$ Volume of $\mathrm{Na}_{2} \mathrm{~S}_{2} \mathrm{O}_{3}$ Used for the Blank

$\mathrm{V}_{2}=$ Volume of $\mathrm{Na}_{2} \mathrm{~S}_{2} \mathrm{O}_{3}$ Used for the Sample.

\section{Results}

The results for the characterization of the shea butter oil and the shea butter biodiesel as well as the ASTM standard for biodiesel is presented in Table 1 below. It summarizes the results of the characterization, physicochemical and fuel properties of the shea butter oil before and after transesterification.

Table 1 Results for the Characterization of the Shea Butter Oil and Biodiesel

\begin{tabular}{lllll}
\hline S/N & Properties & Shea Butter Oil & Shea Butter Biodiesel & ASTM Standard D6751 \\
\hline 1 & Yield $(\%)$ & 48 & 91 & - \\
2 & Density $\left(\mathrm{Kg} / \mathrm{m}^{3}\right)$ & 923.84 & 887.61 & $575-900$ \\
3 & Refractive Index & 1.464 & 1.441 & 1.432 \\
4 & Viscosity $\mathrm{mm}^{2} / \mathrm{s}$ at $40^{\circ} \mathrm{C}$ & 4.5 & 3.62 & $1.9-6.0$ \\
5 & Acid Value $(\mathrm{mgKOH} / \mathrm{g})$ & 1.84 & 0.37 & 0.8 maximum \\
6 & Saponification $\quad$ Value & 189.53 & 265.81 & 120 maximum \\
7 & (mgKOH/g) & & & 93 maximum \\
8 & Flash Point $\left({ }^{\circ} \mathrm{C}\right)$ & 338 & 34.24 & 14 maximum \\
\hline
\end{tabular}

\section{Discussion}

Since the shea kernel is non-edible, and the fact that the shea oil is itself useful in many ways, ranging from medicinal, house-hold and production of biodiesel, and the ever raising shea butter oil market value world-wide, its oil yield and properties are the most important characteristic to be considered and analyzed. The oil yield from the shea kernels collected from Hadejia in Jigawa state, Nigeria was found to be $48 \%$, and this was found to be within the range of 41 $53 \%$ as reported by Okullo et al., (2010) for the shea butter kernels obtained from different districts of Uganda. The result also agrees with that reported by Odisu et al., (2019) who reported an oil yield of $47 \%$ for shea nuts obtained from Benin City, Edo State, Nigeria. On the other hand, the yield for the transesterified shea butter oil in this research work was found to be $91 \%$, and this report agrees with similar report by Jude and Benjamin (2014) who reported a yield of $88 \%$ of biodiesel from shea butter oil using homogeneous catalysts. The high yield of shea butter oil and its 
biodiesel contents from the samples from Hadejia in Jigawa state makes Hadejia town a potential source of shea butter oil.

Density gives information on the weight of the oil or fat and the solid content at a specific temperature. For the density, it can be seen that the density of the shea butter oil dropped from 923.82 to $887.61 \mathrm{Kg} / \mathrm{m}^{3}$ after the transesterification process that produced the biodiesel. The density of the biodiesel is found to be within the range of the ASTM standard $\left(575-900 \mathrm{Kg} / \mathrm{m}^{3}\right)$, and is an agreement to that reported by Jude and Benjamin (2014); Maitera et al., (2017) and Odisu et al., (2019) who reported the densities for the shea butter biodiesel as 881.5, 890.0 and 866.4 Kg/m ${ }^{3}$ respectively. Low density value can be interpreted as to indicate a more complete ester conversion.

Refractive index refers to the ratio of the speed of light in a vacuum to that in the oil under examination which is related to the degree of saturation and the ratio of cis/trans double bonds, and can also provide hints on the oxidative damage (Hamilton and Rossell 1986). In this study, the refractive index of the oil was measured and found to be 1.464 for the shea butter oil, and 1.441 for the shea butter biodiesel, and all these values were found to fall within the range of a typical refractive index of shea nut oil (1.463-1.467) as reported by Hamilton and Rossell (1986), and also within the ASTM standard of 1.432. Refractive index can be used for rapid sorting of oils and fats that are under the suspicion of being adulterated (Olaniyan and Oje 2007), it is also one of the important physical characteristics for the identification of oils and fats.

The viscosity of oil or fat refers to its resistance to flow, and it increases with the molecular weight of the oil or fat, while it decreases with the increasing rate of unsaturation and high temperature (Nourrechni et al., 1992). The viscosity of the shea butter oil and its biodiesel analyzed in this research were respectively found to be 4.5 and $3.62 \mathrm{~mm}^{2} / \mathrm{s}$ at $40^{\circ} \mathrm{C}$, and all these were found to be within ASTM standard of $1.9-6.0 \mathrm{~mm}^{2} / \mathrm{s}$. The values obtained in this study were in agreement with reports by some other researchers (Jude and Benjamin 2014; Chibor et al., 2017; Maitera et al., 2017 and Odisu et al., 2019). The high viscosity value of the shea butter oil at $40^{\circ} \mathrm{C}$ is an indication of its high resistance to flow, and this implies that shea butter oil contains more saturated fatty acids and more solid fats at a temperature of $40^{\circ} \mathrm{C}$, this makes it a suitable source of hard stock (solid fraction) for bakery shortening and margarine production (Chibor et al., 2017). Viscosity is also one of the most important criteria in evaluating the quality of diesel, with high viscosity leading to operational problems including engine deposits.

Understanding the changes associated with the acid value of oils and fats is necessary as it plays a vital role in the spoilage or rancidity of the fat or oil. The acid value is the measure of the amount of potassium hydroxide (mg) necessary to neutralize the free acids in $1 \mathrm{~g}$ of the fat or oil (Ikaya et al., 2013). The acid value of the shea butter oil analyzed in this research was found to be $1.84 \mathrm{mgKOH} / \mathrm{g}$, and this value is near similar to $1.76 \mathrm{mgKOH} / \mathrm{g}$ reported by (Chibor et al., 2017), but lower than 2.3-3.0 mgKOH/g as reported by Okullo et al., (2010). On another hand, the acid value of the shea butter biodiesel analyzed in this study was found to be $0.37 \mathrm{mgKOH} / \mathrm{g}$, and this is below the maximum acid value of 0.8 $\mathrm{mgKOH} / \mathrm{g}$ set by ASTM. Similar reports by Mulugetta (2009) and Enweremadu and Alamu (2011) also fall below the maximum ASTM acid value. Egan et al., 1985 was of the view that the acid value of fat is the measure of the extent to which the glycerides in the oils have been decomposed by the action of the enzyme lipase or any other action.

Saponification value is the number of milligrams of $\mathrm{KOH}$ required to react completely to saponify $1 \mathrm{~g}$ of oil, and it is inversely proportional to the molecular weight of the sample; therefore could be used to access the molecular weight of the sample oil under investigation (Schumann and Siekmann 2005). The saponification value of the shea nut oil analyzed in this study was found to be $189.53 \mathrm{mgKOH} / \mathrm{g}$, while that of the shea butter biodiesel was found to be $265.81 \mathrm{mgKOH} / \mathrm{g}$, and these values are above the maximum value of $120 \mathrm{mgKOH} / \mathrm{g}$ set by the ASTM. However, the values relate to the saponification value of $227.94 \mathrm{mgKOH} / \mathrm{g}$ for groundnut oil recorded and reported by Amo-Tanta and Onigbinde 2013. The saponification value is one of the highest qualities of vegetable oils making them suitable for industrial use, especially in the manufacture of soaps, detergents and shampoo products (Maitera et al., 2017). It can be seen that the saponification value of the oil (189.53 $\mathrm{mgKOH} / \mathrm{g}$ ) increases to $265.81 \mathrm{mgKOH} / \mathrm{g}$ after transesterification to the biodiesel, and this contradicts the report by Maitera et al., (2017).

Flash point refers to the temperature at which the fuel ignites when exposed to a heat source. In other words, it is the lowest temperature at which the vapours above the fuel become flammable (Blomqvist et al., 2015). It is an important guide towards the safe handling, storage and transportation of the fuel (Maitera et al., 2017). The flash points of $338^{\circ} \mathrm{C}$ and $96^{\circ} \mathrm{C}$ for the shea butter and its biodiesel respectively obtained in this study were found to be above the minimum required flash point of $93^{\circ} \mathrm{C}$ set by the ASTM. The shea butter biodiesel is can be classified as safe and non-hazardous owing to the value of its flash point. The value of the flash point of the biodiesel produced in this research work is lower than that reported by Odisu et al., (2019) who reported flash points of $173.5^{\circ} \mathrm{C}$ and $178^{\circ} \mathrm{C}$ for samples of shea butter biodiesel. 
Iodine value, a chemical constant used to measure unsaturation or the average number of double bonds in an oil or fat sample, is defined as the number of grams of iodine that could be added to $100 \mathrm{~g}$ of oil (Shahidi 2005). The iodine value of the shea butter oil analyzed in this study was found to be $35.52 \mathrm{~g} / 100 \mathrm{~g}$, while for the biodiesel it was found to be $34.24 \mathrm{~g} / 100 \mathrm{~g}$, and all these values were found to be lower than $61.00 \mathrm{~g} / 100 \mathrm{~g}, 61.31 \mathrm{~g} / 100 \mathrm{~g}$ and $60.37 \mathrm{~g} / 100 \mathrm{~g}$ respectively reported by Olayinan and Oje (2007), Ikaya et al., (2013) and Obibuzur et al., (2014). However, the values obtained in this study are still above the maximum value set by the AST. Low iodine value indicates that the oil is rich in saturated fatty acids, and this ensured stability against oxidation and spoilage of foods prepared with such oils (Goh 1994). Low iodine also acts as a good source of solid fat during shortening and margarine production.

\section{Conclusion}

Provision of more environmentally friendly, low cost and efficient source of fuel is the subject of discussion globally. Due to the recent crisis in the between the oil producer and consumer countries, efforts need to be intensified to provide alternative sources of fuel energy with special emphasis on cost and environmental stability. This study reports the possibility of extracting and using the oil from the shea butter oil as a source of biodiesel. It was found that the shea butter kernel oil has many of the needed attributes desired for the performance of fuel. The study has confirmed that shea butter kernel may be a useful source of biodiesel, and could offer more opportunities for employment and increase in income. However, further research on additional fuel property measurements and performances on engines need to be carried out.

\section{Compliance with ethical standards}

\section{Acknowledgments}

Our acknowledgment goes to the management of Yusuf Maitama Sule University, Kano who gave full financial, moral and technical support to this research, and also to the chemistry department of the University for their full support and assistance.

\section{Disclosure of conflict of interest}

Some of the materials required for the research had to be obtained from a sister University, and this has not been as easy as it sounds, because it contradicts the policy of our University.

\section{References}

[1] Alajtal AI, Sherami FE and Elbagermi MA. (2018). Acid, Peroxide, Ester and Saponification Values for Some Vegetable Oils Before and After Frying AASCIT Journal of Materials, 4(2), 43-47.

[2] Amo-Tanta, BMW and Onigbinde AO. (2013). Physicochemical Properties and Fatty Acid Profile of Crude Oil Extracts from Three Vegetable Seed Pakistan Journal of Nutrition, 12(7), 647-650.

[3] AOAC International. (2000). Official Methods of Analysis of AOAC Internatinal. 17th Edn. Gaithersburg, MD: AOAC International.

[4] Arjun BC, Martin ST, Suzanne MB, Chris KW and Rafiqul-Islam. (2008). Non-Edible Plant Oils as New Sources for Bidiesel Production, International Journal of Molecular Science, 9(2), 169-180.

[5] Atabani AE, Silitonga AS, Ong HC, Mahlia TMI, Masjuki HH, Badruddin IA and Fayaz H. (2013). Non-Edible Vegetable Oils: A Critical Evaluation of Oil Extraction, Fatty Acid Composition, Biodiesel Production, Characteristics, Engine Performance and Emissions Production, Renewable and Sustainable Energy Reviews, 18, 211-245.

[6] Ayhan D, Abdullah B, Waqar A and Manzoor S. (2016). Biodiesel Production from Non-Edible Plant Oils, Energy Exploration and Exploitation, 34(2), 290-318.

[7] Blomqvist P, Evegren F, Willstrand O and Arvidson M. (2015). Preflash - Preliminary Study of Protection Against Fire in Low-Flash Point Fuel. Science Partner Report. SP Technical Research Institute of Sweden, 1-5.

[8] Canakci M and Van Gerpen J. (1999). Biodiesel Production Via Acid Catalysis, Transactions of the ASAE, 42(5), 1203-1210. 
[9] Chibor BS, Kiin-Kabari DB and Eke-Ejiofor J. (2017). Physicochemical Properties and Fatty Acid Profile of Shea Butter and Fluted Pumpkin Seed Oil: A Suitable Blend in Bakery Fat Production, International Journal of Nutrition and Food Sciences, 6(3), 122-128.

[10] Egan H, Kirk RS and Sawyer R. (1985). Pearson's Chemical Analysis of Foods. Churchill Livingstone, London, 520550 .

[11] Enweremadu CC and Alamu OJ. (2011). Development and Characterization of Biodiesel from Nigerian Shea Nut Butter (Vitellaria paradoxa), International Agrophysics, 24, 29-34.

[12] Enweremadu CC, Rutto HL and Peleowo N. (2011). Performance Evaluation of a Diesel Engine Fueled with Methy Ester of Shea Butter,World Academy of Science Engineering and Technology, 79, 135-139.

[13] Ghadge SV And Raheman H. (2005). Biodiesel Production from Mahua (Madhuca indica) Oil having High Free Fatty Acids, Biomass Bioenergy, 28(6), 601-605.

[14] Gimbun J, Ali S and Kanwal CC. (2013). Biodiesel Production from Rubber Seed Oil using a Limestone Based Catalyst, Advances in Materials Physics and Chemistry, 2(4), 138-143.

[15] Goh E. (1994). Formulation of Lauric Oil Containing Food Products and their Performances. In: Proceedings of World Conference on Lauric Oils: Sources, Processing and Applications, Applewhite, T. H(ed). The American Oil Chemists Society, USA, 38-103.

[16] Hamilton RJ and Rossell JB. (1986). Analysis of Oils and Fats. Elsevier Applied Science. New York, Chi, 53.

[17] Heroor SH and Bharadwaj SDR. (2013). Production of Bio-Fuel from Crude Neem Oil and its Performance. International Journal of Environmental Engineering and Management, 4, 425-432.

[18] Ho DP, Ngo HH and Guo W. (2014). A Mini Review on Renewable Sources for Biofuel. Bioresource Technology, $169,742-749$.

[19] Ikaya JK, Umengar LN and Lobee A. (2013). Effect of Extraction Methods on the Yield and Quality Characteristics of Oils from Nut, Journal of Food Research Science, 2, 1-12.

[20] Ike E, Yerima JB and Dikko AB. (2018). Determination of the Viscosity and Density of Mahogany Seed Oil IOSR Journal of Engineering, 08(2), 08-13.

[21] Jude E and Benjamin A. (2014). Production of Biodiesel from Shea Butter Oil using Homogeneous Catalysts, Leonardo Journal of Sciences, 12, 39-48.

[22] Kanna AR, Purushotham ST, Sreerag KS, Sooraj PS, Vipin Raj RA and Arun KS. (2017). Experimental Analysis of Flash Point of Lubricating oil. International Refereed Journal of Engineering and Science, 6(4), 53-55.

[23] Kotoka F, Tulashie SK and Setsoafia DD. (2017). Production of Bioethanol from Liquid Waste from Cassava Dough during Garri Processing, Biofuels, 10(4), 493-501.

[24] Maitera ON, Louis H, Dass PM, Akakuru UO and Joshua Y. (2017). Production and Characterization of Biodiesel from Coconut Extraxt (Cocos nucifera), World News of Natural Sciences, 9, 62-70.

[25] Mulugetta Y. (2009). Evaluating the Economics of Biodiesel in Africa, Renewable and Sustainable Energy reviews, Elsevier, 13(6-7), 1592-1598.

[26] Nourrechni H, Teoh BC and Clement ID. (1992). Viscosity of Vegetable Oils and Fatty Acids, Journal of American Chemical Society, 69, 1184-1188.

[27] Obibuzur JU, Abigor RD, Omamor I, Omoriyekemen V, Okogbenin EA and Okunwaye T. (2014). A Two-Year Seasonal Survey of the Quality of Shea Butter Produced in Niger State of Nigeria, African Journal of Food Scieces, 8(2), 64-74.

[28] Odisu T, Akemu A, Obahiagbon KO and Anih EC. (2019). Comparative Studies on the Production of Biodiesel from Shea Nut Oil by Acid Catalyzed and Supercritical Transesterification Processes, Journal of Applied Sciences and Environmental Management, 23(2), 349-357.

[29] Okullo JBL, Omujal F, Agea JG, Vuzi PC, Namutebi A, Okello JBA and Nyanzi SA. (2010). Physico-Chemical Characteristics of Shea Butter (Vitellaria Paradoxa C.F. Gaertn.) Oil from the Shea Districts of Uganda, African Journal of Food Agriculture Nutrition and Development, 10(1), 2070-2084.

[30] Olaniyan AM and Oje K. (2007). Quality Characteristics of Shea Butter Recovered from Shea Kernel through Dry Extraction Process, Journal of Food Science Technology, 44, 404-407. 
[31] Ong HC, Mahli TMI and Masjuki HH. (2011). Comparison of Palm Oil, Jatropha curcas and Calophyllum inophyllum for Biodiesel: A Review. Renewable and Sustainable Energy Reviews, 15(8), 3501-3515.

[32] Padhi SK and Singh RK. (2010). Optimization of Esterification and Transesterification of Mahua (Madhuca indica) Oil for Production of Biodiesel, Journal of Chemical and Pharmaceutical Research, 2(5), 599-608.

[33] Ramadhs AS, Jayaral S and Muraleedharan C. (2004). Use of Vegetable Oils as IC Engine Fuels: A Review, Renewable Energy, 29(5), 727-742.

[34] Samuel KT, Pranjal K, Francis K, Oscar KS and Livingstone Q. (2018). Biodiesel Production from Shea Butter: A Suitable Alternative Fuel to Premix Fuel, Materialia, 3, 288-294.

[35] Sarin R, Sharma M, Sinharay S and Malhotra RK. (2007). Jatropha-Palm Biodiesel Blends: An Optimum Mix for Asia, 86, 1365-1371.

[36] Schumann K and Siekmann K. (2005). Soaps. Ullmann's Encyclopedia of Industrial Chemistry. Weinheim: WileyVCH, 247.

[37] Shahidi F. (2005). Quality Assurance of Fats and Oils: In: Bailey's Industrial Oil and Fats Products, Shahidi F. (Ed). 6A Edn. John Wily and Sons Inc. USA, 47.

[38] Shay EG. (1993). Diesel Fuel from Vegetable Oils: Status and Opportunities, Biomass Bioenergy, 4, $227-242$.

[39] Thangaraj B, Ramachandran KB and Raj SB. (2014). Homogeneous Catalytic Transesterification of Renewable Azadirachta indica (Neem) Oil and its Derivatives to Biodiesel Fuel Via Acid/Alkaline Esterification Processes, International Journal of renewable Energy and Biofuels, 11, 1-16.

[40] Tulashie SK and Salifu S. (2017). Potential Production of Biodiesel from Green Microalgae, Biofuels, 11(2), 201208.

\section{How to cite this article}

Datti Y, Musa I, Isma'il S, Mustapha A, Muhammad MS, Ado AS and Ahmad UU. (2020). Extraction, production and characterization of biodiesel from shea butter (Vitellaria paradoxa C. F. Gaertn) Obtained from Hadejia, Jigawa State, Nigeria. GSC Biological and Pharmaceutical Sciences, 11(3), 208-215. 